\title{
A Reviews on Behaviour of Industrial Chimneys
}

\section{Sachin Mutkure1, Dr. Rashmi Bharatey², Dr. Dilip Mase ${ }^{3}$}

${ }^{1}$ M-Tech. Scholar, Department of Civil Engineering, G.H. Raisoni college of Engineering, Nagpur, Maharashtra, India.

${ }^{2}$ Assistant Professor, Department of Civil Engineering, G.H. Raisoni college of Engineering, Nagpur, Maharashtra, India. ${ }^{3}$ Director, P. T. Mase \& Associates. Nagpur, Maharashtra, India

\begin{abstract}
Review article contains various research paper related to the topic chimney and forces acting on it like the seismic force, earthquake forces as well as geographical condition, fundamental time, model analysis and software analysis and modelling of the chimney. Various software is used to analysis and modelling of the chimney.in this paper discuss various modelling concept and problem behind them. The purposes of this paper are to identify the problem associate with a chimney as per Indian geometrical condition as well as the seismic zone in India. This review paper help to improve knowledge regarding design and modelling methodology aspects.
\end{abstract}

Keywords : RCC Chimney, Strengthening, Model analysis, NDT, Industrial structure, Seismic analysis.

\section{INTRODUCTION}

A structure which allows hot air or toxics pollutant gases to expose to outside atmosphere is known as chimney. Generally, chimneys are made up of Steel and Reinforced concrete. The height of chimney varies up to $400 \mathrm{~m}$. Due to the large height several forces act on it, forces like seismic force, wind force etc. Intensity of force varies according to its height and diameter. During the last few decades, there is significant rise in use of Reinforced concrete chimney because of cheap structure installation and maintenance cost. Though maintenance of steel is minimum compared to concrete stacks, but Concrete chimneys superior to masonry and steel chimneys from architectural point of view. Due to industrialisation there is rise in requirement of design of chimney .This designs are according to Indian code of practise and earthquake loads become important criteria. Top diameter of chimney, velocity at which gas will leave the chimney and height are the some parameters which needs to be under specified limits.
Throughout the year many chimneys are installed and thus this parameters are of immense important while designing the chimney. While designing section is taken and accordingly stress development is checked. This paper consists of literature review of all latest papers published on chimneys. This study gives you detail review of the research papers published in the field of industrial chimneys and latest trends in chimneys design and construction. It looks for modelling aspects of chimneys, which also consider case studies, analysis and design using various software, experimentation etc. It also shows a complete study done on chimneys and also provide an updated material for one working in this field. The references included in this paper are mostly concentrated on the review article published.

\section{LITERATURE REVIEW}

"Conditional evaluation of RCC silo using various NDT testing" [1], in this research paper researcher worked on conditional evaluation of RCC silo by 
using various NDT Testing. And method used for testing is ultrasonic pulse velocity, Rebound hammer test, Cover Meter test, core test. For its quality and strength of structure.

"A critical review on modelling of industrial Chimney"[2], in which paper is focused on review of various modelling aspect of Chimney, and various case studies as well as software analysis.

"Dynamic Behaviours of tall Chimney" [3], in this paper discuss about dynamic analysis of tall Chimney which is located in Maharashtra of $275 \mathrm{~m}$.height and analysis with 3 nodded plate elements.

"Governing load for design of RCC Chimney" [4], the paper focused on the effect of wind and earthquake analysis of the structure using various governed load and plot bending moments.

"Seismic analysis of 275m tall RCC Chimney"[5], in this paper research paper focused on analysis of multi fume RC Chimney by using STAD-PRO software and compare time history method and response spectrum analysis.

"Structural retrofitting of reinforced concrete Chimney"[6], the research paper mainly focused on structural strengthening of RC Chimney which is located in Turkey's old iron and steel factory. The reinforced concrete Chimney were build according to the Russian standards in 1975 and analysis in SAP2000. And show the detailing of RC Chimney jacketing.

"A review on parametric study of RC Chimney for different loading condition" [7], research focused on various seismic effect, along and across wind effect, stress, draft code, stack effect on RC Chimney is study. Structure used for study dimension are $220 \mathrm{~m}$ high concrete structure.
"Cracked reinforced concrete wall of Chimneys silos and cooling towers as result of using formworks"[8], research focused which types of crack develop in RC Chimney shell and problem associate with Chimney shell, points considering are durability, design life, causes of reduce durability of Chimney, Chimney repair technique, and method used to restore durability.

“ Upgrade of RC silos using near surface mounted FRP composites"[9], in this paper researcher describe the new technology for repair of RC silo using FRP and NSM (FRP) is used NSM FRP is highly recommended as well as effective solution to strengthening of circular section.

"Strengthening of RC Chimney with FRP Composites"[10], this paper study strengthening of RC Chimney and FRP composite fibre, design of RC Chimney according ACI 307 and detail design philosophy as well as nominal flexural capacity is explain.

"A new vibration damping facility for steel chimneys" [11], the outcome from article is used of damper in steel chimney and problem associate while using damper. And technical implementation. Fluid dampers are used and concept behind passive vibration is proposed for 125 meter height chimney. And study the various drawbacks of RC chimney and steel chimney- head damper.

"Governing for loads of a $60 \mathrm{~m}$ industrial RCC chimney" [12], in this experiment he represented that industrial chimneys generally usually supposed to support essential loads created by seismic force, wind force. Therefore it's essential to examine the dynamic response of chimney to seismic activity and wind loads. As per draft code the deflection at the free finish of the chimney should be inside the permissible limit. The result of wind force for $55 \mathrm{~m} / \mathrm{s}$ wind speed is 
quite vital as compared with the earthquake forces in zone Moment because of earthquake in zone three is nearly up to the combined moment because of wind speed Moment due to earthquake in zone 3 is almost equal to the combined moment..

\section{"MODEL ANALYSIS OF RCC CHIMNEY"[13], in this} paper research discus analysis and design of chimneys and loading are consider as wind and earthquake .and model using FEM based ANSYS software. And effect in natural frequency, displacement, etc. calculated the displacement of chimney is determine.

\section{CONCLUSION}

The current paper focuses on review articles on modelling aspects of the industrial chimney this review article includes case studies, design his survey article incorporates contextual investigations, software examination, includes exact investigation, the structure includes different parameters which ought to be completed with standard code of practices. The modern chimney is significantly impacted by unique loadings. And wind being significant predominant loads, the investigation must be made for all conceivable basic loads and load combinations. And Behaviour of Rereinforced concrete structure. Detail about non-destructive techniques for concrete structure. Aware current trend in repair rehabilitation of tall RC structure.

\section{REFERENCES}

[1]. Vijayakumar Amulya \& A. Dattatreya Kumar "Behaviour of RCC Column Strengthened using Steel Jacketing” International Journal for Research in Applied Science \& Engineering Technology (IJRASET) September 2017.

[2]. N. Lakshmanan, K. Muthumani \& T.S. Krishnamoorthy "Retrofitting Of Reinforced Concrete Structures Using Wrapping Technique" 4th International Conference on Earthquake Engineering, October 2006.

[3]. Prathamesh Dingorkar and Ayush Srivastava "Retrofitting - Comparative Study of RC Jacketing and Frp Wrapping” International Journal of Civil Engineering and Technology (IJCIET) SeptemberOctober 2016.

[4]. Chetan Yalburgimath, Akash Rathod \& S Bhavanishankar " Retrofitting of Reinforced Concrete Beam Using Carbon Fiber Reinforced Polymer Fabric" International Research Journal of Engineering and Technology (IRJET) Oct 2007.

[5]. Tabish Rasool Sheikh, Mohd Kashif Khan, Tabish Izhar " A review on Strengthening of RCC square columns with Reinforced Concrete Jacketing" International Research Journal of Engineering and Technology (IRJET) March 2004.

[6]. Saim Raza, Muhammad K. I. Khan \& Scott J. Menegon "Strengthening and Repair of Reinforced Concrete Columns by Jacketing: State-of-the-Art Review" International Research Journal of Engineering and Technology (IRJET) May -2015.

[7]. Mansoor Ahmad Bhat \& Er. Gurpreet Singh "Retrofitting of reinforced concrete Beams by using carbon fibre reinforced polymer sheets" International Journal of Civil Engineering and Technology (IJCIET) September 2012.

[8]. Kalpesh R. Kolhe, Manish D. Mata "Assessment of Damaged Building by Using Retrofitting Techniques- Case Study" International Journal of Engineering and Techniques - Volume 3 Issue 3, May-June 2017.

\section{Cite this article as :}

Sachin Mutkure, Dr. Rashmi Bharatey, Dr. Dilip Mase, "A Reviews on Behaviour of Industrial Chimneys", International Journal of Scientific Research in Science and Technology (IJSRST), Online ISSN : 2395-602X, Print ISSN : 2395-6011, Volume 7 Issue 3, pp. 118-120, May-June 2020. Available at doi : https://doi.org/10.32628/IJSRST207329 Journal URL : http://ijsrst.com/IJSRST207329 